\title{
Perbandingan Metode FJ. Mock dan NRECA untuk Transformasi Hujan Menjadi Debit pada DAS Metro Kabupaten Malang, Jawa Timur
}

\section{Karunia Waasiu Widyaningsih $^{1 *}$, Donny Harisuseno ${ }^{1}$, Widandi Soetopo ${ }^{1}$}

\author{
${ }^{1}$ Jl. Mayjen Haryono 167, Lowokwaru, Malang, 65145, Indonesia \\ *Korespondensi Email : karuniawaasiu@gmail.com
}

\begin{abstract}
A process of converting rain data to runoff or discharge flow is called the rain transformation process. The transformation of rain into discharge is affected by the physical characteristics of the watershed and its land used. Discharge data in a watershed functions is as a measure of the amount of discharge available in a river which is useful in improving the management of water resources. This study purpose is to determine the results of the calculation of rain to discharge which located in the Metro DAS, Malang Regency. The methods analyzed by researchers is the FJ. Mock and NRECA methods. The results of the calculation from these methods are then compared with the rain data, because the AWLR discharge in the Sub Metro Watershed is considered not suitable to be the discharge of observations in this study. Based on the analysis results, the most suitable method for calculating the rainfall discharge in the Sub Metro Watershed is NRECA method with a determination coefficient $\left(\mathrm{R}^{2}\right)=0.792$, and a correlation coefficient $(r)=0.887$.
\end{abstract}

\section{Keywords : Discharge, FJ. Mock, NRECA, Rainfall Transformation.}

Abstrak: Suatu proses untuk mengubah data hujan ke limpasan atau aliran debit disebut dengan proses transformasi hujan. Transformasi hujan menjadi debit ini dipengaruhi oleh karakteristik fisik DAS serta penggunaan lahannya. Data debit pada suatu DAS berfungsi sebagai pengukur besaran debit yang tersedia pada suatu sungai yang bermanfaat dalam meningkatkan pengelolaan Sumber Daya Air. Studi ini bertujuan untuk mengetahui hasil perhitungan hujan menjadi debit berlokasi di DAS Metro, Kabupaten Malang. Metoda yang dianalisa oleh peneliti adalah metoda FJ. Mock dan NRECA. Hasil perhitungan dari metode-metode tersebut kemudian dibandingkan dengan data hujan, dikarenakan data AWLR pada Sub DAS Metro ini dianggap kurang layak untuk menjadi debit observasi dalam studi ini. Berdasarkan hasil analisis metode yang paling sesuai untuk perhitungan debit hujan pada Sub DAS Metro adalah metode NRECA dengan nilai Koefisien Determinasi $\left(R^{2}\right)=$ 0,792 serta Koefisien Korelasi $(r)=0,887$.

Kata Kunci :Alih Ragam Hujan, Debit, FJ. Mock, NRECA. 


\section{Pendahuluan}

Proses pemodelan yang mengubah data hujan menjadi aliran atau limpasan disebut dengan alih ragam hujan. Data debit pada suatu DAS berfungsi sebagai pengukur besaran debit yang tersedia pada suatu sungai yang bermanfaat dalam meningkatkan pengelolaan Sumber Daya Air sehingga dapat terpenuhinya hajat hidup manusia, hewan maupun tumbuhan [1].

Pentingnya perencanaan hidrologi tidak lepas dari data pencatatan yang telah dilakukan dalam kurun waktu tertentu. Bisa dipastikan bahwa terdapat stasiun pencatatan hujan dalam suatu DAS, namun sering kali terdapat kesulitan untuk mendapatkan data debit dikarenakan tidak terdapatnya stasiun pencatatan data debit atau alatkpencatatan data debit yang telah rusak pada sungai tersebut sehingga tidak dapat difungsikan lagi. Maka, dibutuhkan pemodelan yang dapat mengubah data hujan menjadi limpasan atau debit. Dua metode yang sering digunakan di Indonesia adalah metode FJ. Mock dan NRECA.

Simulasi perhitungan dari metode Mock mengacu dari water balance, yang artinya sirkulasi serta distribusi airnya bervariasi, namun volume air total di bumi tidak berubah [2]. Model Mock dapat diterapkan jika data sungai tidak tersedia (meskipun ada, namun range datanya tidak mencukupi dalam perhitungan). Data debit dalam penelitian merupakan informasi berdasarkan dari pendekatan perkiraan (empiris) dengan menggunakan data hujan [3].

Model NRECA ialah model hujan-aliran yang cukup simple [4]. NRECA menggunakan indeks kapasitas penyimpanan kelembaban tanah, laju pembuangan dari penyimpanan air tanah ke sungai, data curah hujan harian, dan evapotranspirasi potensial data [3].

Konsep dasar daur hidrologi adalah konsep yang dijadikan dasar dari semua model hujan aliran. Pembedanya hanyalah cara menginterpretasikan mulainya hujan hingga menjadi aliran [5].

Parameter lain yang mempengaruhi perhitungan metode ini yaitu runoff [6]. Model runoff digunakan sebagai alat untuk menggambarkan proses hidrologi [7]. Bagian hujan yang mengalir di atas tanah pada saat hujan yang mana setelahnya akan melimpas ke sungai dan berakhir di laut disebut dengan aliran limpasan hujan. Karena limpasan hujan inilah yang akan mempengaruhi aliran sungai yang dialirkannya. Pada permulaan simulasi untuk penyimpanan air tanah harus ditentukan penyimpanan awal yang nilainya bergantung pada waktu dan geologi setempat [8].

Tujuan dari studi ini adalah untuk mengetahui simulasi hasil alih ragam hujan-aliran dengan metode NRECA dan FJ. Mock dengan periode bulanan. Selain itu juga untuk mengetahui hasil analisis kesesuaian metode antara debit AWLR atau debit aliran sungai dengan hasil simulasi perhitungan metode NRECA serta FJ. Mock sehingga menemukan metode yang paling sesuai dengan periode bulanan.

\section{Lokasi Penelitian}

Lokasi studi yang digunakan adalah di DAS Metro Kabupaten Malang. Secara administratif DAS Metro ini terletak di antara Kota Malang, Kota Batu dan Kabupaten Malang. Lokasi penelitian ini berada pada DAS Metro, dengan geografis $112^{\circ} 27^{\prime} 49.85^{\prime \prime}-112^{\circ} 366^{\prime} 56.56^{\prime \prime}$ BT serta $7^{\circ} 55^{\prime} 13.08^{\prime \prime}-$ 758'36.14"LS. Dengan luas wilayah DAS Metro berkisar $\pm 298,064$ km2.

Pemilihan lokasi studi adalah di DAS Metro Kabupaten Malang. Hal ini didasarkan bahwa terdapat stasiun pencatat Debit (AWLR) pada DAS ini yang mana membantu proses kalibrasi simulasi model hujan-aliran. Dari keberhasilan simulasi ini, maka diharapkan beberapa parameter yang diteliti dari salah satu model yang teruji dapat dimanfaatkan untuk DAS di sekitar DAS Metro yang tidak terdapat stasiun data debit aliran sungai dan mempunyai karakteristik yang sama dengan DAS ini. 


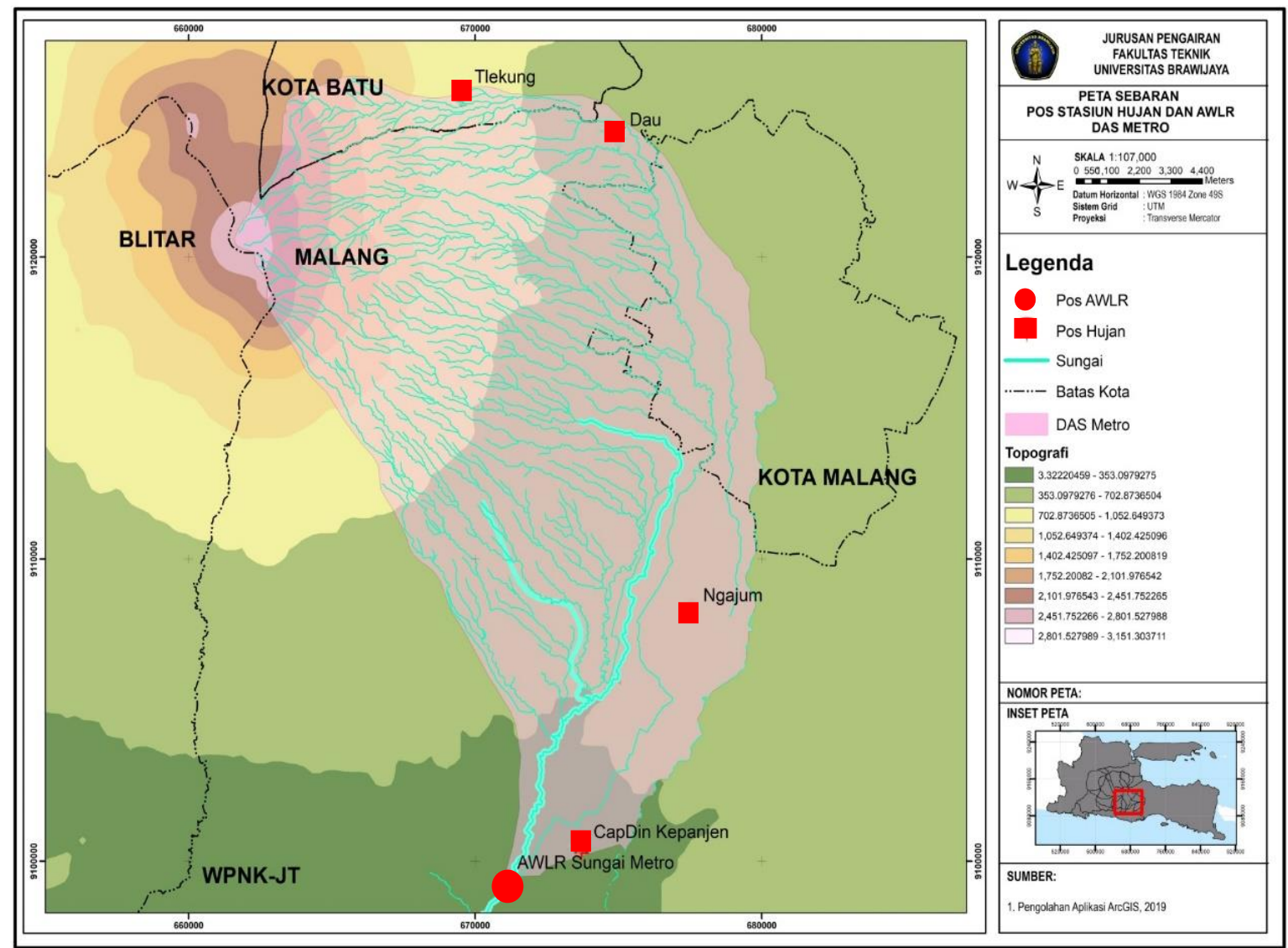

Gambar 1. Peta Lokasi Studi

\section{Metodologi Penelitian}

3.1. Data

Data yang diperlukan dalam penelitian ini meliputi:

1. Data klimatoilogi 14 tahun (2004-2017)

2. Data curah hujan 14 tahun (2004-2017)

3. Data Debit AWLR 10 tahun (2008-2017)

4. Peta tata guna lahan DAS Metro

5. Peta stasiun hujan dan AWLR

6. Peta poligon Thiessen DAS

\section{NRECA}

Natural Rural Electrical Cooperation Agency atau disebut sebagai model NRECA ini merupakan model yang dikembangkan oleh Cranford yang merupakan model hujan-limpasan yang cukup sederhana. Model berikut dapat difungsikan sebagai model analisa debit berdasarkan kesetimbangan air dalam DAS.

Perhitungan pendugaan debit dengan metode NRECA adalah sebagai berikut [1]:

$$
Q=(G F+D R F) x A
$$

Dengan :

$$
\begin{aligned}
& \begin{array}{l}
A \quad=\text { luas DAS }\left(\mathrm{km}^{2}\right) \\
D R F \quad=\text { limpasan langsung }(\mathrm{mm})
\end{array} \quad \text { exc. }=\text { kelebihan kelengasan } \\
& \begin{aligned}
\text { Exc } & =\text { extrat } x(P-A E T), \text { dengan } \\
G F & =\text { limpasan air tanah }(\mathrm{mm}) \\
& =\text { GWF } \mathrm{x}(P S U B \times \text { exc. }=G W S)
\end{aligned} \\
& \text { Extrat } \quad=\text { rasio kelebihan kelengasan }
\end{aligned}
$$




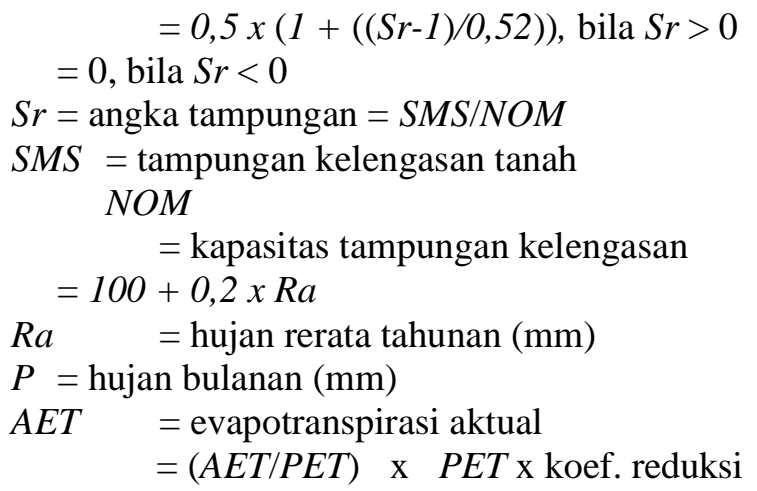

Terdapat lima parameter yang menjelaskan karakteristik DAS yang berpengaruh pada keluaran sistem, yaitu:

1. Nominal

Indeks kapasitas dari kelengasan tanah dapat dihitung dengan rumus sebagai berikut:

$100+C \cdot R a$

Pers. 2

Dengan:

$C=0,2$

$R a=$ Hujan tahunan (mm)

Nilai Nominal bisa berkurang hingga $25 \%$ pada DAS yang jenis tanamannya terbatas dan tanah penutupnya tipis.

\section{2. $P S U B$}

$P S U B$ merupakan parameter yang menjelaskan karakteristik tanah permukaan $(0-2 \mathrm{~m})$ dimana nilainya 0,3 untuk tanah jenuh air dan 0,9 untuk tanah lolos air dan 0,5 untuk daerah tangkapan air yang normal.

$0,5<P S U B \leq 0,9=$ dengan daerah akuifer permeable yang besar,

$0,3 \leq P S U B<0,5=$ dengan daerah akuifer terbatas serta lapisan tanah tipis.

\section{3. $G W F$}

GWF ialah parameter yang menjelaskan karakteristik tanah permukaan (2 - 10) dimana nilainya 0,8 untuk tanah jenuh air, 0,2 untuk tanah lolos air dan 0,5 untuk daerah tangkapa hujan yang normal.

$0,5<G W F \leq 0,8=$ untuk daerah dengan aliran menerus yang kecil,

$0,2 \leq G W F<0,5=$ untuk daerah dengan aliran menerus yang bisa diandalkan.

4. Simpanan Kelengasan Tanah (Soil Moisture Storage / SMS)

Besarnya cadangan air ditentukan oleh selisih tampungan akhir dan tampungan awal disebut dengan simpanan kelengasan tanah. Evapotranspirasi yang menentukan besarnya tampungan, selain itu juga terdapat hujan dan kelebihan kelengasan yang menjadi limpasan langsung dan imbuhan air tanah. Untuk simpanan kelengasan tanah dapat dihitung dengan:

$S M_{i}=S M_{i-1}+\Delta$ Stor $_{i-1}$

Pers. 3

Dengan:

$S M_{i} \quad=$ simpanan kelengasan tanah bulan ke $i$

$S M_{i-1} \quad=$ simpanan kelengasan tanah bulan ke $i-1$,

$S M_{0} \quad=$ simpanan kelengasan awal, ditentukan dengan coba-coba

$\Delta$ Stor $_{i-1}=$ perubahan simpanan kelengasan tanah bulan ke $i-1$.

5. Simpanan Air Tanah (Ground Water Storage / GWS)

Dalam proses ini, menentukan tampungan awal dengan coba-coba. Tampungan awal bulan kemudian ditentukan dengan persamaan berikut:

$B S G_{i+1}=E S G_{i}-$ GWFlow $_{i}$

Pers. 4

Dengan:

$B S G_{i+1} \quad=$ tampungan awal bulan ke $i+1$,

$E S G_{i} \quad=$ tampungan akhir bulan ke $i$,

GWFlow $_{i}=$ aliran air tanah bulan ke $i$ 
Sementara tampungan akhir dihitung menggunakan persamaan berikut:

$E S G_{i}=B S G_{i}+R E C H_{i}$

Pers. 5

Dengan:

$\mathrm{RECH}_{i} \quad=$ kelebihan kelengasan tanah yang masuk dalam tanah pada bulan ke $i$

\section{FJ. Mock}

Volume air yang keluar masuk dan air penyimpanan tanah juga diperhitungkan dalam metode Mock. Air hujan yang jatuh kemudian berevapotranspirasi sesuai dengan jenis tanaman yang menutupi lahan tangkapan hujan. Kemudian perhitungan debit dilakukan berdasarkan limpasan total dikalikan luasan daerah tangkapan air [2]. Evapotranspirasi pada metode Mock, ialah evapotranspirasi yang dipengaruhi oleh jenis tanaman, jumlah hari hujan dan permukaan tanah [9].

Terdapat 5 parameter yang menggambarkan karakteristik DAS yang berpengaruh besar terhadap keluaran sistem, yaitu sebagai berikut:

1. Singkapan Lahan $(\mathrm{m})$

Persentase singkapan lahan ini mempengaruhi evapotranspirasi aktual yang terjadi, yang membedakannya dengan evapotranspirasi potensial. Nilai singkapan lahan dibagi menjadi beberapa jenis seperti tabel dibawah ini [10].

Tabel 1: Singkapan Lahan Sesuai Tata Guna Lahan

\begin{tabular}{ccc}
\hline No & Jenis Penggunaan Lahan & $m(\%)$ \\
\hline \hline 1. & Hutan Lebat & 0 \\
2. & Lahan Tererosi & $10-40$ \\
3. & Lahan Pertanian & $30-50$ \\
\hline
\end{tabular}

2. Koefisien Infiltrasi

Infiltrasi merupakan proses masuknya air hujan pada permukaan tanah dan batuan dari gaya gravitasi dan kapiler. Kemampuan ini dinyatakan sebagai infiltrasi $(I)$, sedangkan kapasitas untuk masuknya air hujan dinyatakan sebagai kapasitas infiltrasi $(k)$.

$$
I_{n}=W_{s_{n}} \cdot C i
$$

Pers. 6

Dengan:

$I_{n} \quad=$ Infiltrasi $(\mathrm{mm})$, per bulan tertentu dalam $1 \mathrm{~m}^{3}$

$W_{s_{n}} \quad=$ water surplus $(\mathrm{mm})$, per bulan tertentu dalam $1 \mathrm{~m}^{2}$

$C i=$ koefisien Infiltrasi, $n$ menyatakan perhitungan dalam bulan tertentu $n$.

3. Kapasitas Kelembaban Tanah (Soil Moisture Capacity)

Besarnya kapasitas kelembaban tanah ditentukan oleh kondisi porositas lapisan tanah atas tiap $1 \mathrm{~m}^{2}$. Besarnya SMC dalam perhitungan ketersediaan air ini diperkirakan berdasar pada kondisi porositas lapisan tanah permukaan di Daerah Airan Sungai (DAS)

4. Simpanan Awal (Initial Storage)

Simpanan awal / Initial Storage adalah perkiraan besarnya volume pada saat awal dimulainya perhitungan. Untuk musim hujan, besar Initial Storage bisa sama dengan kapasitas kelembaban tanah, sedangkan untuk musim kemarau padaKumumnya dipakai data kadar air tanah (DAS).

5. Faktor Resesi Air Tanah $(k)$

Faktor resesi air tanah yaitu perbandingan antara air tanah dari suatu bulan dengan aliran air tanah di awal bulan. Faktor resesi aliran tanah dipengaruhi oleh sifat geologi DAS. Pada perhitungan ketersediaan air metode Mock, besaran nilai $k$ didapat umumnya berkisar 0,4-0,7 sehingga dapat dihasilkan aliran seperti yang diharapkan. 


\section{Analisa Kesesuaian Metode}

Analisa kesesuaian metode merupakan analisa yang bertujuan untuk membandingkan danNmelihat kesesuaian dari hasil perhitungan dengan data debit aliran sungai (AWLR) pada lokasi studi. Analisa ini dilakukan dengan beberapa pengujian, diantaranya:

1. Uji Efisiensi Nash-Sutcliffe

Uji yang menunjukkan tingkatHketelitian dari korelasi hubungan antara data pengamatan dan data perhitungan disebut dengan Uji Efisiensi Nash-Sutcliffe. UjiJEfisiensi NashSutcliffe ini digunakan untuk mengevaluasi keabsahan model. Pengujian ini dilakukan dengan membandingkan simulasi model perhitungan dan hasil pengamatan, dengan persamaannya sebagai berikut [11]:

$$
E_{N S}=1-\frac{\sum_{i=1}^{n}\left(Y_{o b s}-Y_{s i m}\right)^{2}}{\sum_{i=1}^{n}\left(Y_{o b s}-\overline{Y_{o b s}}\right)^{2}}
$$

Pers. 7

Dengan:

$$
\begin{array}{ll}
E_{N S} & : \text { koefisien Nash-Sutcliffe } \\
n & : \text { jumlah data, } \\
Y_{S i m} & : \text { nilai hasil pemodelan }\left(\mathrm{m}^{3} / \mathrm{det}\right), \\
Y_{o b s} & : \text { nilai pengamatan }\left(\mathrm{m}^{3} / \mathrm{det}\right) \\
Y_{o b s} & : \text { rata-rata nilai pengamatan }\left(\mathrm{m}^{3} / \mathrm{det}\right),
\end{array}
$$

\section{Root Mean Square Error (RMSE)}

Suatu ukuran kesalahan yang berdasarkan selisih dari dua nilai yang bersesuaian untuk mengukur ketepatan suatu data disebut dengan Uji Root Mean Square Error (RMSE). Apabila semakin rendah nilai $R M S E$ maka menunjukkan tingkat error semakin kecil sehingga pemodelan semakin baik, namun jika nilai RMSE semakin besar maka tingkat error semakin besar pula sehingga hasil estimasi pemodelan semakin tidak tepat dibandingkan dengan hasil pengamatan.

Persamaan dalam menghitung RMSE adalah [11]:

$R M S E=\sqrt{\frac{\sum_{i=1}^{n}\left(\hat{y}_{i}-y_{i}\right)^{2}}{n}}$

Dengan:

Pers. 8

$$
\begin{aligned}
\text { RMSE } & =\text { nilai Root Mean Square Error, } \\
\hat{y}_{i} & =\text { nilai pemodelan }\left(\mathrm{m}^{3} / \mathrm{det}\right), \\
y_{i} & =\text { nilai pengamatan }\left(\mathrm{m}^{3} / \mathrm{det}\right), \\
n & =\text { jumlah data }
\end{aligned}
$$

3. Mean Absolute Error (MAE)

Mean Absolute Error (MAE) merupakan analisis yang menentukan kesalahan absolut dari selisih antaraJnilai pemodelan dan nilai pengamatan. Semakin kecil nilai MAE pada suatuJmodel, maka semakin kecil juga penyimpangan dari nilai pengamatan [12]. Persamaan Mean Absolute Error (MAE) dinyatakan sebagai berikut:

$$
M A E=n^{-1} \sum_{i=1}^{n}\left|e_{i}\right|
$$

Pers. 9 


$$
r=\frac{(n)\left(\sum x y\right)-\left(\sum x\right)\left(\sum y\right)}{\sqrt{\left(n \cdot \sum x^{2}-\sum(x)^{2}\right) \cdot\left(n \cdot \sum y^{2}-\sum(y)^{2}\right)}}
$$

Dengan:

$M A E \quad=$ nilai Mean Absolute Error,

$P_{i} \quad=$ nilai hasil permodelan $\left(\mathrm{m}^{3} / \mathrm{det}\right)$,

$O_{i} \quad=$ nilai pengamatan $\left(\mathrm{m}^{3} / \mathrm{det}\right)$,

$n \quad=$ jumlah data,

4. Koefisien Korelasi

Koefisien korelasi merupakan suatu analisa yang membahas derajat asosiasi analisa regresi yang memiliki hubugan sebab-akibat. Nilai koefisien ini berkisar $1,0 \geq r \geq-1$ [13].

Persamaan untuk mengetahui besarnya koefisien korelasi yang menyatakan derajat hubungan antara variabel $\mathrm{X}$ dan $\mathrm{Y}$ adalah :

$$
r=\frac{(n)\left(\sum x y\right)-\left(\sum x\right)\left(\sum y\right)}{\sqrt{\left(n \cdot \sum x^{2}-\sum(x)^{2}\right) \cdot\left(n \cdot \sum y^{2}-\sum(y)^{2}\right)}}
$$

Dengan:

$x \quad=$ rerata dari $X_{i}$,

$y \quad=$ rerata dari $Y_{i}$,

$n \quad=$ jumlah data

\section{Kesalahan Relatif $(\mathrm{Kr})$}

Kesalahan relatif $(K r)$ adalah analisis yang digunakan untuk mengetahui besaran persentase kesalahan relatif yang terjadi terhadap nilai hasilIpemodelan dengan cara menghitung persentase perbedaan antara hasil pemodelan dengan hasil pengamatan. Hal ini dimaksudkan untuk memperoleh keyakinan terhadap nilai pemodelan. Persamaan dalam menentukan kesalahan relatif adalah sebagai berikut:

$$
K_{r}=\left(\frac{X_{a}-X_{b}}{X_{a}}\right) \times 100 \%
$$

Pers. 12

Dengan:

$K_{r} \quad:$ kesalahan relatif $(\%)$

$X_{a} \quad$ : nilai pengamatan $\left(\mathrm{m}^{3} / \mathrm{det}\right)$

$X_{b} \quad$ : nilai hasil pemodelan $\left(\mathrm{m}^{3} / \mathrm{det}\right)$

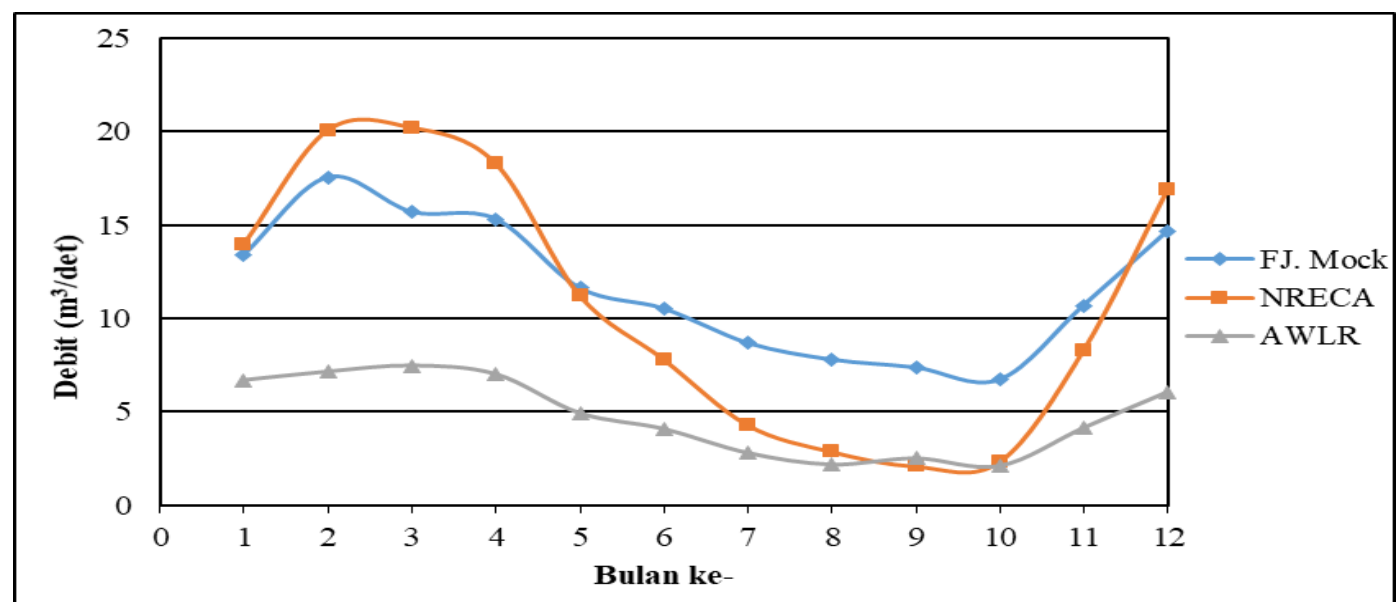

Gambar 2. Grafik Perbandingan Debit Perhitungan dan Pengamatan Periode Bulanan 


\section{Hasil dan Pembahasan}

Pada rekapitulasi hasil nilai simulasi alih ragam hujan menjadi debit model Mock tahun 20042017 didapatkan nilai minimum debit FJ Mock berkisar $=2,915 \mathrm{~m}^{3} /$ det dan maksimal $=25,084$ $\mathrm{m}^{3} /$ det. Sedangkan untuk Metode NRECA, nilai debit berkisar minimum $=0,312 \mathrm{~m}^{3} / \mathrm{det}$ dan maksimal $=32,857 \mathrm{~m}^{3} /$ det.

Dari hasil analisis kesesuaian metode dengan debit pengamatan didapatkan kesimpulan bahwa metode NRECA yang dinilai mendekati untuk memenuhi kriteria dalam analisa kesuaian metode. Namun nilai Nash-Sutcliffe (NSE) yang negatif (-) dan nilai Kesalahan Relatif yang melebihi 100\% pada kedua metode, menyebabkan kedua metode tersebut dinilai jauh dari memuaskan untuk analisis ini. Sehingga diperlukan analisis kesesuaian metode dengan curah hujan pengamatan untuk mendapatkan metode yang sesuai dengan cara menganalisa kuat tidaknya hubungan linier antara hujan dan debit.

Nilai Nash-Sutcliffe (NSE) yang negatif (-) dan nilai Kesalahan Relatif yang melebihi $100 \%$ dari kedua metode ini diakibatkan oleh debit pengamatan yang kurang memiliki akurasi yang baik sehingga nilai perhitungan metode alih ragam hujan-debit terlampau jauh dengan debit pengamatan.,

Pada Gambar 2 dapat disimpulkan bahwa nilai debit pengamatan terlampau jauh dan kurang fluktuatif dibanding nilai kedua debit metode. Dari bulan pertama sampai dengan bulan ke 12 debit pengamatan cenderung stabil, sedangkan kedua metode simulasi mengalami fluktuasi yang cukup tinggi pada pergantian bulan basah ke bulan kering yang dipengaruhi oleh curah hujan pengamatan.

Tabel 2: Hasil Analisa Kesesuaian Metode dengan Debit Pengamatan

\begin{tabular}{ccc}
\hline Metode & FJ Mock & NRECA \\
\hline Nash-Sutcliffe $(N S E)$ & $-11,814$ & $-13,882$ \\
Kesalahan Relatif $(K R)(\%)$ & 163,240 & 103,130 \\
Mean Absolute Error $(M A E)$ & 6,912 & 6,016 \\
Koefisien Determinasi & 0,947 & 0,966 \\
$\left(R^{2}\right)$ & 0,973 & 0,983 \\
Koefisien Korelasi $(r)$ & & \\
\hline
\end{tabular}

Hasil analisa kesesuaian metode dengan debit pengamatan pada Tabel 2 dinilai kurang memuaskan pada masing-masing metode karena nilai Nash-Sutcliffe (NSE) yang negatif (-) dan nilai Kesalahan Relatif yang melebihi $100 \%$.

Kurang akuratnya debit pengamatan ini disebabkan oleh pengukuran pada lapangan yang tidak konsisten, yaitu dilakukan hanya satu kali pada setiap bulannya. Sedangkan untuk mendapatkan data debit pengamatan diperlukan minimal setiap hari pengambilan datanagarkdapat dikatakan sebagai data yang konsisten. Ketidak konsitenan ini akan mempengaruhi sistem dari simulasi hujan-debit. Maka dari itu, penuliskmelakukan analisis kesesuaian metode dengan menilai pengaruh curah hujan pengamatan dengan debit simulasi yang ada.

Tabel 3: Hasil Analisis Kesesuaian Metode dengan Curah Hujan Pengamatan

\begin{tabular}{ccc}
\hline Metode & Koefisien Determinasi $\left(R^{2}\right)$ & Koefisien Korelasi $(r)$ \\
\hline FJ Mock & 0,787 & 0,887 \\
NRECA & 0,792 & 0,890 \\
\hline
\end{tabular}

Hasil metode NRECA didalam analisis kesesuaian metode dengan curah hujan pada Tabel 3 dinilai lebih unggul dibandingkan dengan metode FJ. Mock. Namun, nilai analisis kesesuaian metode dari FJ. Mock mempunyai selisih yang tipis dengan metode NRECA sehingga dapat dikatakan bahwa 
kedua metode tersebut sama-sama dapat menjadi acuan untuk menghitung simulasi hujan-debit pada DAS Metro.

\section{Kesimpulan dan Saran}

Berdasarkan dari perhitungan yang sudah dilakukan, ditarik kesimpulan bahwa nilai minimum debit F.J Mock berkisar $=2,915 \mathrm{~m}^{3} /$ det dan maksimal $=25,084 \mathrm{~m}^{3} /$ det. Untuk Metode NRECA, nilai debit berkisar minimum $=0,312 \mathrm{~m}^{3} /$ det dan maksimal $=32,857 \mathrm{~m}^{3} / \mathrm{det}$.

Hasil data debit AWLR dengan debit empiris metode NRECA dan FJ. Mock menghasilkan nilai yang jauh berbeda. Hal tersebut diakibatkan oleh pengambilan data debit pengamatan yang dilakukan pada DAS Metro ini hanya satu kali dalam satu bulan. Hal ini mengakibatkan data tersebut dianggap kurang layak untuk dijadikan data debit acuan dalam studi. Sedangkan untuk mendapatkan data debit pengamatan diperlukan minimal setiap hari pengambilan data agar dapat dikatakan sebagai data yang konsisten. Sehingga dalam studi ini dilakukan analisis kesesuaian metode dengan data hujan. Hasil analisa menunjukkan bahwa metode yang dinilai sesuai pada simulasi hujan-aliran di DAS Metro ini adalah Metode NRECA, hal tersebut bisa dilihat dengan nilai Koefisien Determinasi $\left(R^{2}\right)$ sebesar 0,792, dan Koefisien Korelasi ( $r$ ) 0,887. Sedangkan FJ Mock dengan besaran Koefisien Determinasi $\left(R^{2}\right)$ sebesar 0,787, dan Koefisien Korelasi $(r)$ 0,887.

Saran yang dapat diajukan oleh penulis pada studi ini yaitu agar mendapatkan hasil perbandingan alih ragam hujan-debit yang lebih baik, diperlukan adanya data pengukuran debit pengamatan harian sebagai pembanding. Selain itu juga diharapkan untuk menjadi masukan penelitian selanjutnya bahwa pada DAS Metro dapat menggunakan metode NRECA untuk perhitungan hujan-debit.

\section{Daftar Pustaka}

[1] L. Alby, "Perbandingan Metode Alihragam Hujan Menjadi Debit dengan FJ Mock dan NRECA di DAS Kemuning Kabupaten Sampang", Jurnal Teknik Pengairan, Malang : Universitas Brawijaya, Vol. 2, No. 1, 2018

[2] S. Wahyuni, "Perbandingan Metode Mock dan NRECA untuk Pengalihragaman Hujan ke Aliran", Jurnal Rekayasa, Vol. 13 (2) : 541-637, 2014

[3] I. Komariah, and T. Matsumoto, "Application of Hydrological Method for Sustainable Water Management in the Upper-Middle Ciliwung (UMC) River Basin, Indonesia”, Journal of Water and Environment Technology, Vol. 17, No.4: 203-217, 2019

[4] Z. Indra, "Analisis Debit Sungai Munte dengan Metode Mock dan Metode NRECA untuk Kebutuhan Pembangkit Listrik Tenaga Air", Jurnal Sipil Statik, Universitas Sam Ratulangi. Vol. 1, No. 1 (34-38), 2012

[5] E. Setyono, "Pemakaian Model Diterminsistik untuk Transformasi Data Hujan Menjadi Data Debit pada DAS Lahor", Jurnal Media Teknik Sipil, Vol. 9, No. 1, 2011

[6] I. S. D. Sebayang, and C. Trianing, "Comparison Rainfall-Runoff Model for Ciujung-Sabagi River. International Conference on Design, Engineering and Computer Sciences”, IOP Conf. Series: Materials Science and Engeering 453 012025. Doi: 10.1088/1757899X/453/1/012025, 2018

[7] E. H. Abushandi, and B. J. Merkel, "Application of IHACRES rainfall-runoff model to the wadi Dhuliel arid catchment, Jordan", Journal of Water and Climate Change, 2(1), 56-71, 2011

[8] L. M. Limantara, "Analisa Keandalan Tampungan Waduk di Embung Tambak Pocok Bangkalan”, Jurnal Teknik Sipil, Vol. 23, No. 2, 2016 
[9] R. P. Kesuma, A. H. Wahyudi, and Suyanto, "Aplikasi Metode MOCK, NRECA, TANK MODEL dan Rainrun di Bendung Trani, Wonotoro, Sudangan dan Walikan", E-Jurnal Matriks Teknik Sipil, Vol. 1 No. 4, 2013

[10] N. Hadisusanto, Aplikasi Hidrologi, Yogyakarta: Mediutama, 2010

[11] Indarto, Hidrologi Dasar Teori dan Contoh Aplikasi Model Hidrologi, Jakarta: Bumi Aksara, 2012

[12] C. J. Willmot, and K. Matsuura, "Advantages of the mean absolute error (MAE) over the root mean square error (RMSE) in assessing average model performance", Climate Research, vol. 30, no. 1, 2005, 79-82. JSTOR, 2005

[13] Soewarno, Hidrologi Aplikasi Metode Statistik untuk Analisa Data Jilid 2, Bandung: Nova, 2015 